\title{
Sickonomics: Diagnoses and Remedies
}

\author{
Geoffrey M. Hodgson
}

The Business School, University of Hertfordshire, De Havilland Campus, Hatfield, Hertfordshire AL10 9AB, UK

www.geoffrey-hodgson.info

g.m.hodgson@herts.ac.uk

\section{April 2010}

To be published in the Review of Social Economy

\begin{abstract}
In their recent analysis of the alleged decay in modern economics, Ben Fine and Dimitris Milonakis claim to find its source and origin in the 'marginal revolution' of the 1870s. They argue that this development led to 'methodological individualism' and the detachment of economics from society and history. I contest their account of the marginal revolution and of the role of Alfred Marshall among others. They also fail to provide an adequate definition of methodological individualism. I suggest that neoclassical economics adopted a denuded concept of the social rather than removing these factors entirely. No such removal is possible in principle. It is also mistaken to depict neoclassical economics as the science of prices and the market. In truth, neoclassical economics fails to capture the true nature of markets. I consider some sketch an alternative explanation of the sickness of modern economics, which focuses on institutional developments since the Second World War.
\end{abstract}


Several books recently have addressed the changing face of modern economics. 1 Some take a cooler empirical approach; others are more critical of the outcome. 2 Among the critical surveys, the two books by Ben Fine and Dimitris Milonakis (2009, Milonakis and Fine, 2009) stand out. These works have been widely acclaimed, and have received both the 2009 Isaac Deutscher Memorial Prize and the 2009 Gunnar Myrdal Prize awarded by the European Association for Evolutionary Political Economy. In this essay I concentrate my remarks on the last two books, but I shall make some reference to other contributions.

The two books by Fine and Milonakis are not meant to be fun to read. They lay out in historical fashion the regress of economics in two hundred years from a rounded and inclusive science to 'an arcane branch of mathematics' that fails to deal 'with real economic problems' (Friedman 1999, p. 137). As Mark Blaug (1997, p. 3) similarly observed: 'Modern economics is sick ... Economists have converted the subject into a sort of social mathematics in which analytical rigour is everything and practical relevance is nothing.' Fine and Milonakis explore where things went wrong. It is a depressing story, not simply because of its content but also (as the authors acknowledge) because it is likely to be

1 The author is very grateful to Wilfred Dolfsma and anonymous referees for comments on an earlier version on this essay.

2 David Colander's (2005, 2009) work offers a more empirical and dispassionate approach. Tony Lawson (2006) and Fred Lee (2009) present mutually contrasting and remarkably different analyses from that offered by Ben Fine and Dimitris Milonakis (2009, Milonakis and Fine, 2009). 
ignored by mainstream economists. They are unlikely to be attracted by the non-mathematical, social and historical issues that are thematic in these volumes. I share these grave concerns about our profession.

These detailed and widely-researched volumes force us to confront these problems. Fine and Milonakis try to diagnose the sickness, and consider how the malady may be cured. As they put it:

mainstream economics is increasingly subject to an esoteric and intellectually inextricable technicism that is absolutely intolerant of alternatives and only allows them to survive on its margins. Despite its considerable and long-standing methodological and theoretical fragilities, there is no sign that this situation is liable to change as a result of internally or externally generated critique. (Fine and Milonakis 2009, p. 165)

Writing two books of this seriousness and length is no small achievement. They try to use the history of ideas to illuminate the wrong turnings of the past and to identify the sources of current problems. Surely this demonstrates that the history of economic thought is not merely a dusty obsession with old texts: it can have a great deal of instructive relevance for today. I know that their authors and I share not only a concern with the present state of economics but also we are jointly preoccupied with the question of the boundaries of economics and the other social sciences. In that respect I found much interesting and valuable material in these two books_(Hodgson 2001). ${ }^{3}$

3 I wish to thank them for their generous acknowledgement of one of my own books in this area (Hodgson 2001). 
But despite many strong points I believe that much of the central line of reasoning is deficient or wrong. In the following section I outline what I understand to be the main features of their long argument. Subsequently I shall explain why I think that several key claims are flawed. At later stages I shall introduce alternative diagnoses and consider other possible remedies.

\section{The central claims}

The first volume (Milonakis and Fine 2009) is a critical history of economic thought from Adam Smith to the postwar 'formalist revolution' in economics. They consider the contracting boundaries of economics as a discipline and how it has changed internally. They revere much of both classical and Marxian political economy and argue that adverse symptoms in the discipline can be traced back to the subsequent 'marginalist revolution' of the 1870s. The second volume (Fine and Milonakis 2009) expands this claim by arguing that many adverse developments in economics during the twentieth century can be traced back to that fateful decade of marginalism's triumph. Our authors allege that:

The marginalist revolution had taken the social and the historical out of the economy in a dual sense, by resorting to methodological individualism and by detaching the market/economy from society. (Fine and Milonakis 2009, p. 8)

\section{And similarly:}

the marginalist revolution had the effect of taking the social (and historical) out of economics both by focusing on the (asocial) 
individual and limiting itself to the science of the market. (Fine and Milonakis 2009, p. 12)

There are a number of claimed consequences here. Several other passages in these volumes testify to these. According to these authors, the 'marginalist revolution' supposedly and eventually led to:4

(a) the adoption of methodological individualism,

(b) the depiction of the individual as a rational, utility-maximiser,

(c) the depiction of the individual as 'asocial' and the removal of the 'social' from economics,

(d) the removal of the historical dimension from economics,

(e) increasingly deductivist and ahistorical approaches to theory, and

(f) a narrower redefinition of economics as the science of prices and the market.

Much of this is immediately questionable. For example, especially in the light of claims (c) and (f), how do our authors deal with Lionel Robbins's (1932) apparently different (re)definition of economics as the 'science of choice' and Gary Becker's $(1976,1981)$ wider application of neoclassical economic analysis to non-market and 'social' phenomena such as the family? Do these moves undermine the claim of Fine and Milonakis that economics has become defined as the science of markets, and has abandoned the social? Fine and Milonakis (2009, pp. 8-9)

4 The seven propositions $(\mathrm{a})$ - (g) below are claims that 1 eExtracted from the two volumes- (See for example-Milonakis and Fine $t_{2} t_{-} 2009$, pp. $2,6,11-12,15,26,93,218,249)_{2}$ and Fine and Milonakis ${ }_{2} t_{2} 2009$, pp. 8, $12,17,22,31,131)$. 
answer that in practice these later moves amounted to the treatment of 'social' phenomena as if they were like markets:

the link between the economic and the social meant for Becker the application of the neoclassical technical economic apparatus to the social sphere and treating other areas of the social cosmos as if they were markets, rather than bringing the social back into economic theorising on any other terms.

This suggests a further important claim made by the authors:

(g) when marginalist economic analysis was later extended to 'social' phenomena it was obliged to treat them as if they were markets.

Let me put my own view. Out of these seven claims, I am in qualified agreement with three. I am mostly in accord with (b), (d) and (e). Concerning (b) it is indisputable that the assumption of rational, utility maximising behaviour came to dominate economics during the twentieth century, although I would date its full hegemony much later than the 1870s (especially considering the prominence of American institutionalism in the first half of the twentieth century). But - as we would all agree - by the 1970s, to challenge such an assumption was to make one virtually unemployable as an economist, even if such strictures were relaxed after 1990.5

I am also broadly in accord with (d)_- I have argued-(Hodgson 2001). that s Several developments including marginalism pushed economics in an overly-general direction, to the point of detachment with real but historically specific phenomena. But I do not believe that it was the outcome of marginalism alone.

5 See the discussion of proposition(e) below. 
Concerning (e) there is no doubt that during the twentieth century the subject became much more axiomatic and deductivist. But there are challenges to the view that these trends persisted with full force beyond 1990 (Colander 2005, Colander et al. 2004, Davis 2006). Notably these accounts are dismissed by Fine and Milonakis (2009, pp. 167-9).

Regarding the other four claims ((a), (c), (f) and (g)), I believe that they are either too vague or wrong. My worries include the imprecise use of the terms 'methodological individualism', 'social', and 'the market', and the thesis that after the 1870 s economics increasingly defined itself (explicitly or implicitly) in 'market' terms.

Correct diagnosis is vital because it can lead to effective remedies. In the next section I shall examine the seven claims in the context of the history of ideas. Did the 'marginalist revolution' lead to the outcomes as alleged? The two sections after that will criticise the flawed claims from an analytical point of view. We then move on to alternative diagnoses and remedies.

\section{The central claims in historical perspective}

Milonakis and Fine see the 'marginalist revolution' as the source of the woes of economics. Milonakis and Fine (2009, p. 118) wrongly claim that the German historical school were 'in opposition to marginalism'. In fact they were among the earliest developers of marginalist doctrine, as Alfred Marshall himself acknowledged. Influenced by earlier German thinkers, the founder of the historical school Wilhelm Roscher proposed a subjective theory of value in 1854 and Karl Knies - a member of the historical school who strongly influenced Marshall - put the principle of 
diminishing marginal utility at the core of the theory of price (Ekelund and Hebert 2002, pp. 200-1).

Given such observations, established-researchers within the history of economic thought have moved away from the notion that there was a pronounced 'marginalist revolution' in the 1870s. Careful historians of ideas have shown clearly that it was less of a sudden revolution than an intermittent process, traceable back to the writings of a variety of economists working as early as the 1830s (Howey 1960, Black et al. 1973, Ekelund and Hebert 2002). Furthermore, its impact was delayed. It was left to Marshall to tie the threads together. Prior to 1890 , most of the published general histories of economic thought failed to mention the term 'marginal utility'. No written account of this supposed 'marginalist revolution' appeared until well into the twentieth century. No such dramatic revolution was noticed by economists who worked in the 1870 s - it was more a matter of incremental change from the 1830 s to the 1890 s and beyond. 6

Partly because Marshall played a major role in the construction of marginalism, Fine and Milonakis are keen to depict him as a villain. Unfortunately there are several inaccuracies and misleading suggestions in their account.

6 According to the JSTOR database, there is no appearance of the terms 'marginal revolution' or 'marginalist revolution' in any leading English language journal of economics before 1950 (Burns 1950). The term probably appeared in some monographs before that date, but I have been unable to trace any examples. 
It gives a false impression to repeat that 'Marshall's main adversaries were to be found amongst the British Historical School' (Milonakis and Fine 2009, p. 118) or 'his main protagonists were provided by the British Historical School' (p. 142) unless one also immediately makes it clear that among the historical school there were also some of Marshall's closest and acknowledged allies.

The authors do their best but fail to show that Marshall became a general antagonist of the historical school. They (p. 185) note that Marshall lauded the historical school only in the past tense in his inaugural lecture of 1885 , implying that he no longer thought of them as worthy. This is a non sequitur. One can do no more than applaud contributions that exist in the past. And use of the past tense does not itself imply that any links are severed. Their claim that he also criticised the historical school's 'lack of theory' is without any direct support from Marshall's own texts. The suggestion that Marshall's praise for the historical school ended in 1885 is contradicted by repeated multiple acknowledgements of the methodological, theoretical and empirical contributions of the historical school in every edition of his Principles from 1890 until Marshall's death (Hodgson 2005).

Furthermore, Marshall had a major theoretical dispute with only one member of the historical school, namely William Cunningham, notwithstanding his policy differences with Herbert Foxwell and others over the matter of free trade. After reading Cunningham's work, few would defend his vulgar empiricism that Marshall so ably demolishes. Cunningham was a Comtean positivist (at a time when such views were fashionable) who believed that if economic theory were possible at all, it would somehow emerge from extensive fact-gathering. For Cunningham (1887, p. 8): political economy must 'for the present be content to 
observe and classify and describe and name as other sciences have been'. Such crude atheoretical empiricism is methodologically indefensible. It understandably drew Marshall's fire.

In their brief and unsatisfactory account of the Marshall-Cunningham debate, Marshall's claim that Cunningham has misinterpreted his views is seen by our authors as an attempt to force his views on others and as 'the main substantive issue between the two' (Milonakis and Fine 2009, p. 149). Marshall is acknowledged as being 'generally conciliatory' but 'firmly on the side of allowing for a separate, abstract theory' (p. 152). This fails to get to grips with the issues under dispute.

The truth is that Marshall did believe - like any sensible scientist - in the importance of 'abstract theory'. But he repeatedly argued against its separation from empirical induction or history. In his Principles and elsewhere Marshall (1949, pp. 24, 32) argued that: 'Induction and deduction are both needed for scientific thought as the left foot and the right foot are both needed for walking' and 'the economist must be greedy of facts; but the facts by themselves teach us nothing'. In his letters and elsewhere, Marshall repeated warned of the dangers not only of atheoretical empiricism, but also of treating theory as an end in itself (Whitaker 1996, vol. 2, pp. 256, 280, 393).

In their attempt to convict him as a major villain in their story, Marshall's close and declared affinities with the historical school are mostly ignored (Hodgson 2005). And one piece of affirmative evidence in this regard is so shocking to the authors' negative preconceptions of Marshall that it has to be presented with an exclamation mark (Milonakis and Fine 2009, p. 138), as if to indicate its absurdity. In fact, there are many places where Marshall declares his sympathy with the German historical school. 
Contrary to what Milonakis and Fine (2009, p. 153) declare on the Methodenstreit, there is no substantive evidence that the 'prevailing view at the time was that the abstract theorists had won the argument.' Marshall's continuing allegiance to Gustav Schmoller and other members of the historical school is significant evidence to the contrary. As another case in point, far from acknowledging an Austrian victory in the Methodenstreit, Joseph Schumpeter (1908, pp. 6-7) wrote 'both sides are mostly right ... their sole difference lies in their interests in different problems.' Schumpeter then went on to argue for the coexistence of an ahistorical, universal and Walrasian 'pure economics', alongside the more empirical 'economic history' and 'economic sociology'.

Fine and Milonakis's The account of American institutionalism is more balanced than their narrative on Marshall. But they give insufficient credit to the theoretical aspect of Wesley Mitchell's contribution on business cycles (Mitchell 1927, Friedman 1950). Mitchell did paid more attention to fact-gathering than the development of theory, but that does not mean he ignored the latter. Inappropriately they use the verdict of the hostile neoclassical critic Tjalling Koopmans to establish Mitchell's empiricism (Milonakis and Fine 2009, p. 187). In fact, on close inspection, what Koopmans (1947) really meant by his 'measurement without theory' jibe was measurement without a theory involving individual utility-maximizers (Hodgson 2004, p. 319).

If we are compare Mitchell's tempered empiricism with the atheoretical fact-gathering of Cunningham, then there is a substantive difference, yet while Mitchell is criticised for his empiricist sins, Cunningham is misleadingly depicted as a heroic David against Marshall's Goliath. 
Fine and Milonakis also fail to acknowledge that the-American institutionalists saw a place in their economics for a version of Marshallian marginalism. For example, John Maurice Clark and Wesley Mitchell saw Marshallian price theory as necessary for some types of economic analysis, while they criticized some of the more extreme or 'unrealistic' assumptions found in the neoclassical tradition, such as individual utility maximization, universal diminishing returns, static equilibrium, perfect competition or perfect information. Thorstein Veblen also-rejected rational utility-maximisation. But when Veblen (1892, 1893, 1905) analysed price levels he acknowledged the effects of supply and demand. As Mitchell (1969, vol. 2, p. 685) pointed out, 'Veblen himself at times makes casual, implicit use of orthodox economic theory'. This unacknowledged partial accommodation of Marshallian theory by the institutionalists might suggest that Marshallian marginalism is not as pernicious as Fine and Milonakis claim.

In placing much of the blame on the so-called 'marginalist revolution' of the 1870s, relatively less weight is put on later adverse developments in economics, such as the strong drift to formalism from the 1950s. From significantly different perspectives, both Mark Blaug (1997) and Tony Lawson (1997) see inappropriate formalism as the malady, rather than marginalism. I would have liked to such much more discussion of Blaug's and Lawson's arguments, as well as of the claims by David Colander (2005) and others that mainstream economics is beginning to abandon deductivism and 'rational economic man' in favour of more empiricallygrounded approaches. These issues are controversial and unresolved. Yet they are central to the project of understanding both the trajectory and the malady of contemporary mainstream economics. 


\section{Some central claims dissected - methodological individualism and the social}

I shall now analyse claims (a) and (c). I start with our authors' repeated declaration that one of the gravest negative developments in economics is the adoption of methodological individualism. They never provide a clear and satisfactory definition of this term. It receives it first significant discussion on page 14, where they quote familiar definitions by John Watkins and Jon Elster. But the authors acknowledge neither the ambiguities in these quoted definitions, nor the hugely varied uses of the term by its exponents. They thus resume a well-defined target, whereas in reality there are multiple usages of the term. Sometimes, for example, 'methodological individualism' is wrongly treated in the literature as an ontological statement, e.g. 'society consists of individuals'. Furthermore, Schumpeter's (1908) original definition of the term profoundly contrasts with typical uses today (Hodgson 2007).

I argue elsewhere (Hodgson 2007) that a crucial ambiguity in several definitions (including those provided by Elster and Watkins), is whether methodological individualism means that all social phenomena should be explained (i) in terms of individuals alone, or (ii) in terms of individuals plus interactive relations between individuals. I further argue that (i) is impossible in practice and no social phenomenon has been explained in terms of individuals alone. By contrast, in my view there is nothing wrong with the content of (ii), but it amounts to bringing social structures alongside individuals into the explanation, and thus does not warrant the description of methodological individualism.

Fine and Milonakis are aware of my 2007 article on methodological individualism and they cite it without criticism. Fine and Milonakis (2009, 
p. 21) also cite Kenneth Arrow's (1994) important 'rejection of methodological individualism within economics on the grounds that it cannot be realised in practice.' According to Milonakis and Fine (2009, p. 328), Hodgson (2007) 'has questioned whether a pure form of methodological individualism is to be found in practice, let alone that it is possible giving the necessity of taking something social as given in the first instance'. Yet if my argument is right, then 'something social' is never actually excluded, even from the most blinkered or formal of economic analysis. Arrow (1994) reaches a similar conclusion.

To put it straightforwardly, is post-1870s economics infused by 'methodological individualism' or is it not? Like others, our authors repeatedly suggest that it is. 7 But Fine and Milonakis also seem to concede the arguments of Arrow (1994) and myself that 'methodological individualism' is never found in 'a pure form ... in practice' because of 'the necessity of taking something social as given in the first instance'. By citing Arrow and myself-(significantly without any criticism or rebuttal), our authors seem to accept that the 'pure' form of methodological individualism (invoking explanations in terms of individuals alone) is impossible.

This is such a major concession that it would imply that adequate explanations of social phenomena must always and unavoidably be in terms of both individuals and 'something social'. This would be such an

7 See Milonakis and Fine (2009, pp. 5, 13-14, 45, 102-7, 110, 194, 199, 202, 213, 239, 246-7, 251, 258, 260-1, 264, 268, 271, 294, 301, 310) and Fine and Milonakis (2009, pp. 8, 10, 24, 26, 31, 44, 58, 63, 67, 79, $81,96,107,120,127,134,143,145,147)$. 
elongated version of methodological individualism that it would be unworthy of the name (Hodgson 2007). Because both social and individual elements are necessary explanatory factors, the 'methodological individualism' label is biased and misleading.

So in their repeated statements that post-marginalist economics is driven by methodological individualism do they mean the 'pure' or the 'impure' form? There is a fateful lack of clarity on this issue. Consequently, their proposition that the adoption of methodological individualism is problematic for modern economics lacks analytical bite.

A further result of their apparent concession to Arrow (1994) and myself (that explanations are never in terms of individuals alone and must involve 'something social') is to undermine another central claim of the two books - that economics has allegedly narrowed itself to the point of excluding 'social' factors.

It is highly significant that-Fine and Milonakis never clearly define what they mean by 'social'. I assume this includes all forms of causally interactive relations between individuals (namely social structures, institutions, organisations, positions, conventions and so on), plus emergent properties of these interactive relations (such as social culture), plus significant groupings of individuals (such as social classes).

Arguably, in its treatment of such 'social' phenomena, modern mainstream economics is gravely impoverished. But this does not mean that social factors are (or can be) entirely excluded. In their concessions to Arrow and me our authors seem to accept this. Social or institutional factors may be covert but they are never absent from mainstream analysis. One of the most persistent themes in both historical school and original institutionalist writings is to show that property, markets, prices 
and other factors - which are central to neoclassical economics themselves require specific institutional and cultural foundations. One has only to dip into the works of Gustav Schmoller, Werner Sombart, Max Weber, or John Commons to find such arguments. More recently, Jan Kregel (1998) has shown that the general equilibrium model of Léon Walras assumed quite specific institutional foundations. And social structures (or relations) are central to modern game theory, even if they are not described as such. These accounts do not point to the absence of such factors, but to their covertness and implicitness.

One is left wondering precisely what the reintroduction of the 'social' into economics might mean. In some disfigured and inadequate form, isn't it there already?

Hence the claim that the 'marginalist revolution' led to 'detaching the market/economy from society' (Fine and Milonakis 2009, p. 8) cannot be taken literally (even if we make the necessary correction of inserting 'in theory' after 'detaching'). It is one thing to say that marginalists tried to sever such a link, quite another to say that they succeeded in analysing markets apart from social phenomena. In fact, neither is true. Although several early marginalists saw the economy and markets as facets or sectors of society as a whole, there is no evidence that they tried to rid analysis of the economy or markets of structured interactions between individuals. In the case of Walras (but less so for Marshall) markets and exchange were conceived in an overly abstract form. But 'social' elements remained in all these accounts. The economy was generally seen as part of society, not as apart from it. In any case, to separate the two would be theoretically impossible. 
Consequently the severe problem in modern economics to which Fine and Milonakis allude (but do not clearly identify) is not the exclusion of the social, but the highly impoverished manner by which relational, structural, institutional, organisational and indeed moral factors are treated throughout most discourse in the discipline. 'Social' factors are always there in some form, but the individual building blocks are celebrated and adorned, rather than the humble but vital cement that helps to hold them together.

As a result, claims (a) and (c) are at best misleading and at worst invalid.

\section{More central claims dissected - markets and neoclassical economics}

I now turn to claims ( $f$ ) and $(g)$, which allege that economics after the 'marginalist revolution' became defined more narrowly as 'the science of the market economy' (Fine and Milonakis 2009, p. 22), and that the apparently contrary excursions of modern economists (such as Becker) onto 'social' terrain amount to treating 'social' phenomena as if they were markets.

In the two volumes there is very little evidence to support these two claims. In fact, neither Walras, Menger, Jevons, Edgeworth, Marshall nor Robbins defined economics (or political economy) as 'the science of the market economy', or anything like that.

Marshall, (1949, p. 1) for instance, defines economics as 'the study of mankind in the ordinary business of life'. Economics 'examines that part of individual and social action which is most closely connected with the attainment and with the use of the material requisites of wellbeing.' This 
conception includes industrial organisation, production and consumption, as well as exchange. Marshall's writings were not confined to markets alone - they contain significant discussions of organisation, production and consumption.

In part the problem here is that Fine and Milonakis offer no clear definitions of 'the market' or 'the market economy'. So when we consider Walras's (1874) universalisation of the concept of exchange to cover many forms of human interaction, even before the existence of legally sanctioned property rights, then is this the study of 'the market economy' or not? If Fine and Milonakis were to say that it was, then they would be culpable of universalising the concept of a market in a manner that they rightly criticise. But if they were to deny it, then they would have to acknowledge that Walras did not define economics as the study of the market economy.

It is even more absurd to claim that Robbins defined economics as 'the science of the market economy'. Robbins's actual definition of economics is very important because it inspired Paul Samuelson (1948) and became increasingly influential after the Second World War. 8 It is well known that Robbins defined economics as 'the science of choice'. Fine and Milonakis deal with this by arguing that what is really behind this definition is choice à la marché. They seem to suggest that when Robbins says that economics applies to all choice involving scarcity, in fact he means only choice on the market.

8 See Backhouse and Medema (2009) on how the Robbins definition gradually spread through the discipline. 
This interpretation would not only be odd, but manifestly false, because Robbins actually rebuts such a definition. In the first chapter of his Essay, Robbins (1932) considers several different definitions of the discipline. He notes that the then most popular definition, common to Edwin Cannan, John Bates Clark, Alfred Marshall and Vilfredo Pareto, was that economics is 'the study of the causes of material welfare' (p. 4). Robbins (1932, p. 17) goes on to consider an alternative definition, which he attributes in part to Alfred Ammon (1927), that economics is concerned with 'the behaviour implied by the institutions of the Individualist Exchange Economy'. Robbins responds by arguing that while economists have a central interest in the analysis of exchange economies, this is mainly because so many individual choices are involved. There is no reason, Robbins (1932, pp. 19-20) argues, why economics should be confined to the study of market economies.

Fine and Milonakis propose that when neoclassical economists apply their theories to non-market phenomena - such as the family - they are essentially treating those phenomena as if they were markets. Again this is at best a half-truth. Neoclassical economics does not adequately identify the nature of market decisions and relations. It is wrong to suggest that neoclassical economists have an adequate conception of markets and how they work. In fact, serious definitions and institutional analyses of the market are relatively rare, as Nobel Laureates George Stigler (1967, p. 291), Douglass North (1977, p. 710) and Ronald Coase (1988, p. 7) have all pointed out (Hodgson 2008a). Neither do Fine and Milonakis adequately explain the differences between individual decision-making and interaction inside and outside the market.

Neoclassical economics is about consistent choices and their outcomes. It is not specifically about markets, at least in a rich, 
institutional sense. Adequate concepts of property, contract, exchange and market are absent from standard neoclassical theory (Sened 1997, Hodgson 2001, 2009, Steiger 2008).

For example, as a representative neoclassical economist, Armen Alchian $(1977,238)$ defines the property rights of a person in the universal terms of 'the probability that his decision about demarcated uses of the resource will determine the use.' The upshot of this definition is that if a thief manages to keep stolen goods then he acquires a substantial property right in them. Such ahistorical definitions of property neglect the essential concept of rightful ownership and make no distinction between de jure property and de facto possession (Hodgson 2001, 2009, Steiger 2008).

When attempts are made to discuss exchanges and markets in neoclassical economics, then the main element of the narrative is the increases of utility received by the individuals involved, not the transfer of property rights within a framework of legal institutions. When institutions appear they are discussed primarily in terms of the incentives, information and constraints that they provide for utility-maximizing individuals.

The fact that neoclassical economists frequently use the word 'market' does not mean that they are employing the concepts of property, exchange and market in an adequate or precise way. When Becker (1976, p. 206) wrote that 'a market for marriages can be presumed to exist', markets are little more than a means by which agents can transact in some vague manner, to increase their mutual utility. When he uses the word 'market' it has little institutional substance other than a zone of interaction of individuals with their goods or capacities. 
Precisely because his concepts are so impoverished, Becker fails to make an adequate distinction between (a) sex traded intentionally for money or commodities, and (b) sex based on mutual agreement or desire rather than pecuniary or commodity exchange. Yet modern cultural (and religious) norms make a very strong differentiation between these two types of sexual relationship. Because he deploys no adequate notion of property, commodity exchange or market, these differences are elided in Becker's analysis of the family. By reducing all transactions to the mutual enhancement of 'utility', neoclassical theory is generally heedless to the moral, cultural and institutional distinctions that are involved.

It is thus highly misleading to suggest that neoclassical analysis has some kind of grounding in real markets, and that it is a mistake of the economics imperialists is to treat other social phenomena as if they were markets. Neoclassical theory has at best a tenuous relation to real markets, and hence it is largely unable to treat any social phenomenon in genuinely market terms.

Before we leave markets I wish to make a final point. Although we are familiar with the singular phrase 'the market', and it is difficult to avoid it entirely, it is highly misleading. Once we acknowledge that markets are institutions then it is clear that there is not one market form, but several (Hodgson 1988, 2008a, Mirowski 2007). It is a defect of both neoclassical and Marxist economics to treat the market as a singular entity, and to underestimate its differences in form. Just as many mainstream economists see 'the market' as an unambiguous benefit, most Marxists see it as an unambiguous burden. In fact there are many different kinds of market, with different possible outcome 


\section{Diagnosing sickonomics}

Fine and Milonakis pin much of the blame on the so-called 'marginalist revolution'. I agree in part that marginalism helped to entrench notions of utility-maximisation, which in turn aided mathematical formalism. But the picture is more complicated because not all marginalists were wholly committed utilitarians. I also believe that the growth of marginalism and utilitarianism was much more gradual.

This diagnosis contrasts with Tony Lawson $(1997,2006)$ who sees the problem with economics as inappropriate formalism. Because real world systems are open, there is a general mismatch between (inevitably closed) formal models and reality. If economics is to progress, then formal modelling must be limited to those cases where such regularities pertain, and these appear to be rather rare. Consequently, rather than the so-called 'marginal revolution' of the 1870s, Lawson would locate the full onset of the sickness of economics to the 1950s at the earliest, when mathematical approaches became much more prominent. For him, the principal battle between the heterodox and the mainstream is over the recognition of open systems and the limits of formalism. 9

9 This would logically imply that prominent economists such as Ronald Coase, Friedrich Hayek and Richard Posner (whose work makes very little use of mathematics), many earlier economists such as Adam Smith, David Ricardo, Carl Menger and Alfred Marshall (who used mathematics to a very limited extent, if at all), and perhaps others such as Milton Friedman and Paul Krugman (who have criticised the contemporary abuse of mathematical formalism in economics) should be regarded as 
Frederick Lee tells another very different story. Unlike Fine and Milonakis, Lee (2009, p. 26) believes that 'neoclassical price theory objectively explained how ... the capitalist market system ... worked' for capitalism circa 1900. The problem is that a different form of capitalism developed thereafter, and its analysis was best addressed not with the labour theory of value but with an amalgam of ideas including Gardiner Means' theory of administered prices. Hence Lee (2009, p. 35) claims that 'all the components were available in 1940 to create a relatively complete heterodox economic theory that could replace neoclassical theory.' There are as many differences between these heterodox stances as there is between their work and neoclassical economics. But there is some communality between Lee, on the one hand, and Fine and Milonakis on the other. Both identify neoclassical price theory is the problem, but Lee credits it with some historical veracity.

Fine and Milonakis are more radical. The principal policy conclusion that seems to flow from their analysis is that the salvation of economics lies in reversing the 'marginalist revolution'. I doubt whether this is possible or desirable. The earlier classical and Marxist traditions are inadequate for our needs. 10 Parts of marginalist analysis bring the benefit that they focus on incremental individual incentives, which are important matters both for theory and institutional design. I would prefer

heterodox rather than mainstream. Lawson acknowledges in print that Hayek is heterodox, but none of the others, as far as I am aware.

10 Fine and Milonakis defend a version of the labour theory of value that is redolent of earlier formulations and debates and has lost little of the 'obscurantism' that its critics identified decades ago (Fine and Harris 1976, Hodgson 1977, Steedman 1977). 
a strategy that placed Marshallian and other valuable insights within an institutional and historical context, as several American institutionalists attempted in the 1920s and 1930s (Hodgson 2004).

How did economics become sick? Fine and Milonakis' diagnosis of the causes of its malady is concentrated too much on the influence of ideas, and neglects the manner in which unsatisfactory notions are sustained and impelled by culture, institutions and vested interests. The battle of ideas is important, but in order to win, good generals also understand how people are guided and provisioned.

I wish to sketch very briefly an alternative explanation of the sickness that afflicts economics. At the institutional and cultural level, the most important factor is the global change in the nature of the university. In developed countries before the Second World War, universities were reserved for rich (or intelligent and lucky) minorities. Despite some pressures from business and religious institutions, they often managed to dispense a liberal education and maintained an ethos for the pursuit of truth. But especially since the 1960s, the university has become an institution much more oriented to specialist professional training under the behest of business corporations.

Veblen (1918) observed some of the early stages of this evolution long ago. Others, from different analytical and ideological viewpoints (Callahan 1962, Bloom 1988, Lutz and Field 1998, Kirp 2003, Greenberg 2007) have charted within universities the postwar decline of broad and questioning inquiry, and the rise of narrower forms of professional training targeted for the needs of business. Students are less encouraged to pursue the big questions that haunt our existence. They are urged instead to acquire qualifications that signal skills that can be 
hired on the jobs market. At the same time, professions have become increasingly more specialised (Rueschemeyer 1986, Pryor 1996). Everdeeper specialisation means that Renaissance-like figures with a capacity for an informed overview are both more difficult to create and even less likely to be acknowledged (Hodgson 1999).

The postwar university expansion had the important benefit of bringing higher learning to a much wider segment of the population. Yet it was impelled by perceived economic needs, and the process of commercialisation within higher education was accelerated. Crucially, expanded education systems require much more from the public purse, and democratic and other pressures on governments oblige them to account for the expenditures in performance terms. There were demands that universities should serve the needs of the capitalist economy rather than pursue knowledge for its own sake.

Together these forces eroded enclaves of broad liberal education, vastly expanded professional training oriented towards employment, led to requirements to account for the economic value of university research, and promoted the increasing use of league tables and formalised research assessments to pressure academics to publish their research.

These background institutional forces have impacted upon different disciplines in different ways. Partly as a result of the recruitment of economists into operations research and other applications during the Second World War (Bernstein 2001, Mirowski 2002, Hodgson 2004), economics suffered in a peculiar way because it had established a type and degree of formalism that allowed research output to be assessed largely in terms of mathematical interest and elegance, with less heed to its philosophical or conceptual underpinnings. Economists were judged 
and became employable for their aptitudes for statistical analysis or predictive models.

Because they are no longer educated to take such issues seriously, many mainstream economists no longer care about the deeper meanings or historical origins of theories or concepts, or about big questions concerning economic and social systems. Economists learn 'tools', but little of their ultimate purposes in the grand design. As long as academic economists publish in the higher-ranking economics journals dominated by mathematics, or land lucrative consultancy contracts, they reap their rewards and enhance their reputations.

This process would be difficult or impossible to reverse, but undoing the marginal revolution would be no less tricky. What is necessary, at least for the near future, is for the technically unobsessed economists to establish networks and institutions in which broader modes of enquiry can be preserved. Much greater dialogue is required between economics and the other social sciences. Some reorganisation of the social sciences in universities is also necessary to help achieve this goal. Indeed, there is no apparent justification for the divisions between economics and 'economic sociology', or indeed sociology as a whole (Hodgson 2008b).

\section{Concluding remarks}

Mainstream economics will not be challenged effectively by imprecise discourse. Particularly in the works by Lee (2009) and Fine and Milonakis (2009, Milonakis and Fine, 2009), several key concepts such as 'methodological individualism' and 'reductionism' lack adequate definition. Fine and Milonakis wish to show how political economy lost its 
soul to a narrow version of economics, bereft of 'social' or historical factors. Lee $(2009$, p. 7) similarly complains of the 'ahistorical' and 'asocial' character of neoclassical economics. But one never learns the precise meaning of the 'social', and in any case this description of neoclassical economics is contestable.

As an alternative to vaguely-defined 'methodological individualism' Fine and Milonakis propose an equally imprecise 'methodological structurism' (Fine and Milonakis 2009, pp. 149, 153-9). This amounts to a mélange of the work of Anthony Giddens and a few others, with no acknowledgement of some important criticisms of Giddens' work, and without a mention of other significant recent important social theorists such as Margaret Archer, Roy Bhaskar, Pierre Bourdieu, Norbert Elias, Jürgen Habermas and Niklas Luhmann.

There is nothing original in the history of economic ideas presented by Fine and Milonakis. There is no striking use of new sources and no major reinterpretation of known material. The authors repeat some discredited misinterpretations, particularly concerning Marshall and the 'marginal revolution', which have been shown in the light of scholarship to be flawed. 11

11 On a minor point, the copyeditor of Fine and Milonakis (2009), fails to correct a grammatically grotesque habit of adding in-text Harvard-style references after a comma at the end of a sentence (rather than placing them entirely within brackets like this), thus undermining the structural integrity of the sentence as a whole. The copyeditor of Milonakis and Fine (2009) does a better job. 
By contrast, Lawson's account of the nature of heterodox economics is more rigorous and his work is conceptually more precise. But it offers little guidance on the way forward, save for the questionable project of building an economic analysis (of open systems) that is free of mathematics.

Overall, there is much to complain about the state of modern mainstream economics, but the diagnoses and remedies offered by the authors discussed here are not only discordant, but also flawed and unconvincing. 


\section{References}

Alchian, Armen A. (1977) 'Some Implications of Recognition of Property Right Transaction Costs', in Brunner, Karl (ed.) (1977) Economics and Social Institutions: Insights from the Conferences on Analysis and Ideology (Boston, MA: Martinus Nijhoff), pp. 234-55.

Amonn, Alfred (1927) Objekt und Grundbegriffe der theoretischen Nationalökonomie (Leipzig: Deutlicke).

Arrow, Kenneth J. (1994) 'Methodological Individualism and Social Knowledge', American Economic Review (Papers and Proceedings), 84(2), May, pp. 1-9.

Backhouse, Roger E. and Medema, Stephen G. (2009) 'Defining Economics: The Long Road to Acceptance of the Robbins Definition', Economica, 76, October, pp. 805-820.

Becker, Gary S. (1976) The Economic Approach to Human Behavior (Chicago: University of Chicago Press).

Becker, Gary S. (1981) A Treatise on the Family (Cambridge, MA: Harvard University Press).

Bernstein, Michael A. (2001) A Perilous Progress: Economists and Public Purpose in Twentieth-Century America (Princeton, NJ: Princeton University Press).

Black, R. D. C., Coats, A. W. and Goodwin, C. (eds) (1973) The Marginal Revolution in Economics (Durham: Duke University Press).

Blaug, Mark (1997) 'Ugly Currents in Modern Economics', Options Politiques, 18(17), September, pp. 3-8. Reprinted in Mäki, Uskali (ed.) 
(2002) Fact and Fiction in Economics: Models, Realism and Social Construction (Cambridge and New York: Cambridge University Press).

Bloom, Allan (1988) The Closing of the American Mind (New York: Simon and Schuster).

Burns, Arthur Edward (1950) Review of Theories of Welfare Economics by Hla Myint, in American Economic Review, 40(3), June, pp. 422-4.

Callahan, R. E. (1962) Education and the Cult of Efficiency (Chicago: University of Chicago Press).

Coase, Ronald H. (1988) The Firm, the Market, and the Law (Chicago: University of Chicago Press).

Colander, David C. (2005) 'The Making of an Economist Redux', Journal of Economic Perspectives, 19(1), Winter, pp. 175-98.

Colander, David C. (2009) The Making of a European Economist (Cheltenham: Edward Elgar).

Colander, David C., Holt, Richard P. F. and Rosser, J. Barkley, Jr. (2004) The Changing Face of Economics: Interviews with Cutting Edge Economists (Ann Arbor, MI: University of Michigan Press).

Cunningham, William (1887) Political Economy Treated as an Empirical Science: A Syllabus of Lectures (Cambridge).

Davis, John B. (2006) 'The Turn in Economics: Neoclassical Dominance to Mainstream Pluralism?' Journal of Institutional Economics, 2(1), April, pp. 1-20.

Ekelund, Robert B. Jr. and Hébert, Robert F. (2002) 'The Origins of Neoclassical Economics', Journal of Economic Perspectives, 16(3), Summer, pp. 197-215. 
Fine, Ben and Harris, Laurence (1976) 'Controversial Issues in Marxist Economic Theory', Socialist Register, 1976, pp. 141-78.

Fine, Ben and Milonakis, Dimitris (2009) From Economics Imperialism to Freakonomics: The Shifting Boundaries Between Economics and Other Social Sciences (London and New York: Routledge).

Friedman, Milton (1950) 'Wesley C. Mitchell as an Economic Theorist', Journal of Political Economy, 58(6), December, pp. 465-93.

Friedman, Milton (1999) 'Conversation with Milton Friedman', in Brian Snowdon and Howard Vane (eds), Conversations with Leading Economists: Interpreting Modern Macroeconomists (Cheltenham: Edward Elgar), pp. 122-44.

Greenberg, Daniel S. (2007) Science for Sale: The Perils, Rewards, and Delusions of Campus Capitalism (Chicago: University of Chicago Press).

Hodgson, Geoffrey M. (1977) 'Papering Over the Cracks: Comments on Fine and Harris' Survey of the Current Controversy within Marxist Economics', Socialist Register, 1977, pp. 88-105.

Hodgson, Geoffrey M. (1988) Economics and Institutions: A Manifesto for a Modern Institutional Economics (Cambridge and Philadelphia: Polity Press and University of Pennsylvania Press).

Hodgson, Geoffrey M. (2001) How Economics Forgot History: The Problem of Historical Specificity in Social Science (London and New York: Routledge).

Hodgson, Geoffrey M. (2004) The Evolution of Institutional Economics: Agency, Structure and Darwinism in American Institutionalism (London and New York: Routledge). 
Hodgson, Geoffrey M. (2005) 'Alfred Marshall versus the Historical School?' Journal of Economic Studies, 32(4), 2005, pp. 331-48. Hodgson, Geoffrey M. (2007) 'Meanings of Methodological Individualism', Journal of Economic Methodology 14(2), June, pp. 21126.

Hodgson, Geoffrey M. (2008a) 'Markets', New Palgrave Dictionary of Economics, second edition (Basingstoke: Macmillan).

Hodgson, Geoffrey M. (2008b) ‘Prospects for Economic Sociology’, Philosophy of the Social Sciences, 38(1), March, pp. 133-49.

Hodgson, Geoffrey M. (2009) 'On the Institutional Foundations of Law: The Insufficiency of Custom and Private Ordering', Journal of Economic Issues, 43(1), March, pp. 143-66.

Howey, Ralph S. (1960) The Rise of the Marginal Utility School (Lawrence, KA: University of Kansas Press).

Kirp, David L. (2003) Shakespeare, Einstein, and the Bottom Line: The Marketing of Higher Education (Cambridge, MA: Harvard University Press).

Koopmans, Tjalling C. (1947) 'Measurement Without Theory', Review of Economics and Statistics, 29(3), August, pp. 161-72.

Kregel, Jan A. (1998) ‘Financial Markets and Economic Development: Myth and Institutional Reality', in Nielsen, Klaus and Johnson, Björn (eds) (1998) Institutions and Economic Change: New Perspectives on Markets, Firms and Technology (Cheltenham: Edward Elgar), pp. 24357.

Lawson, Tony (1997) Economics and Reality (London and New York: Routledge). 
Lawson, Tony (2006) 'The Nature of Heterodox Economics', Cambridge Journal of Economics, 30(4), July, pp. 483-505.

Lee, Frederick S. (2009) A History of Heterodox Economics: Challenging the Mainstream in the Twentieth Century (London and New York: Routledge).

Lutz, Frank W. and Field, Robert W. (1998) Business Valuing in Academia: The American University as a Center for Profit or Inquiry? Higher Education, 36(4), December, pp. 383-419.

Marshall, Alfred (1949) The Principles of Economics, 8th edn. (1st edn. 1890) (London: Macmillan).

Milonakis, Dimitris and Fine, Ben (2009) From Political Economy to Economics: Method, the Social and the Historical in the Evolution of Economic Theory (London and New York: Routledge).

Mirowski, Philip (2002) Machine Dreams: Economics Becomes a Cyborg Science (Cambridge and New York: Cambridge University Press).

Mirowski, Philip (2007) 'Markets Come to Bits: Evolution, Computation and Markomata in Economic Science', Journal of Economic Behavior and Organization, 63(2) June, pp. 209-42.

Mitchell, Wesley C. (1927) Business Cycles: The Problem and its Setting (New York: National Bureau of Economic Research).

Mitchell, Wesley C. (1969) Types of Economic Theory: From Mercantilism to Institutionalism, 2 vols., ed. J. Dorfman (New York: Augustus Kelley).

North, Douglass C. (1977) 'Markets and Other Allocation Systems in History: The Challenge of Karl Polanyi', Journal of European Economic History, 6(3), Winter, pp. 703-16. 
Pryor, Frederic L. (1996) Economic Evolution and Structure: The Impact of Complexity on the U.S. Economic System (Cambridge and New York: Cambridge University Press).

Robbins, Lionel (1932) An Essay on the Nature and Significance of Economic Science, 1st edn. (London: Macmillan).

Rueschemeyer, Dietrich (1986) Power and the Division of Labor (Stanford: Stanford University Press).

Samuelson, Paul A. (1948) Economics, 1st edn. (New York: McGrawHill).

Schumpeter, Joseph A. (1908) Das Wesen und der Hauptinhalt der theoretischen Nationalökonomie (München und Leipzig: Duncker und Humblot).

Sened, Itai (1997) The Political Institution of Private Property (Cambridge: Cambridge University Press).

Sombart, Werner (1930) Die drei Nationalökonomien: Geschichte und System der Lehre von der Wirtschaft (München und Leipzig: Duncker und Humblot).

Steedman, Ian (1977) Marx After Sraffa (London: NLB).

Steiger, Otto (ed.) (2008) Property Economics: Property Rights, Creditor's Money and the Foundations of the Economy (Marburg: Metropolis).

Stigler, George J. (1967) 'Imperfections in the Capital Market', Journal of Political Economy, 75(3), June, pp. 287-92.

Veblen, Thorstein B. (1892) 'The Price of Wheat since 1867', Journal of Political Economy, 1(1), December, pp. 68-103. 
Veblen, Thorstein B. (1893) 'The Food Supply and the Price of Wheat', Journal of Political Economy, 1(3), June, pp. 365-79.

Veblen, Thorstein B. (1905) 'Credit and Prices', Journal of Political Economy, 13(3), June, pp. 460-72.

Veblen, Thorstein B. (1918) The Higher Learning in America: A Memorandum on the Conduct of Universities by Business Men (New York: Huebsch).

Walras, Léon (1874) Éléments d'économie politique pure, ou théorie de la richesse sociale (Lausanne : Rouge).

Whitaker, John K. (ed.) (1996) The Correspondence of Alfred Marshall, 3 vols (Cambridge: Cambridge University Press). 